\title{
A ESCOLA E O RENASCIMENTO DA TERRA: EDUCAÇÃO NA TERRA INDÍGENA TE'ÝKUE
}

\author{
Verônica Maria Bezerra Guimarães ${ }^{1}$
}

\begin{abstract}
Resumo
O trabalho analisa o papel da educação escolar na terra indígena Te'ýikue, Caarapó, Mato Grosso do Sul, na construção de projetos de recuperação ambiental. Para isso realizou-se um estudo de caso por meio de pesquisa qualitativa com trabalho de campo mediante técnicas de observação direta, conversas, depoimentos, diários de campo, caminhadas, registro de fotografia e participação em encontros de professores indígenas. A população de estudo apresenta grupos representativos de idosos, rezadores, professores e lideranças. O modelo de educação adotou o ensino da língua materna; a gestão compartilhada da escola; a valorização do conhecimento da cultura kaiowá-guarani; a construção de metodologias e de recursos didáticos próprios e a formação de professores indígenas. Foram realizados: projetos ambientais com a participação da comunidade; viveiro de mudas; Unidade Experimental; reflorestamento; recuperação de nascentes e de microbacias e um fórum de discussões.
\end{abstract}

Palavras-chave: Educação escolar indígena. Terra indígena Te’ýikue. Recuperação Ambiental.

\section{THE SCHOOL AND THE REBIRTH OF THA LAND: EDUCANTION IN TE'YKUE INDIGENOUS LAND}

\begin{abstract}
This study analyzes the role of school education in the Te'ýikue indigenous land, Caarapó, Mato Grosso do Sul, in the conception of environmental recovery projects. A case study was carried out through qualitative research with field work using direct observation techniques, conversations, testimonies, field diaries, hiking, photograph and participation in meetings of indigenous teachers. The study population is characterized by representative groups of: seniors, prayers, teachers and leaders. The education model adopted the teaching of the mother tongue; the shared school management; the valorization of knowledge of the Kaiowá-Guarani culture; the construction of methodologies and of their own didactic resources; and the training of indigenous teachers. Environmental projects were carried out with community participation; nursery of seedlings; experimental unit; reforestation; recovery of springs and micro-basins and a discussion forum.
\end{abstract}

Keywords: Indigenous school education. Te'ýikue indigenous land. Environmental Recovery.

\section{La ESCUELA Y EL RENACIMIENTO DE LA TIERRA: EDUCACIÓN EN LA TIERRA INDÍGENA TE'YKUE}

\section{Resumen}

En este trabajo se analiza el papel de la educación escolar en la tierra indígena Te'ýikue (Caarapó, Mato Grosso do Sul, Brasil) en la construcción de proyectos de recuperación ambiental. Se realizó un estudio de caso de tipo cualitativo con el trabajo de campo por medio de técnicas de observación directa, conversaciones, testimonios, diarios de campo, caminatas,

\footnotetext{
${ }^{1}$ Mestre em Direito Público pela UFPE. Doutora em Desenvolvimento Sustentável pela Unb. Professora adjunta na UFGD.
} 
registros fotográficos y participación en encuentros de profesores indígenas. La población del estudio se caracteriza por grupos representativos de ancianos, curanderos, profesores y líderes. El modelo de educación adoptó la enseñanza de la lengua materna; La gestión compartida de la escuela; La valorización del conocimiento de la cultura kaiowá-guaraní; La construcción de metodologías y de recursos didácticos propios y la formación de profesores indígenas. Se realizaron: proyectos ambientales con la participación de la comunidad; vivero de mudas; unidad experimental; reforestación; recuperación de manantiales y de microcuencas y un Foro de discusiones.

\section{Palabras clave:}

Educación escolar indígena. Tierra indígena Te’ýikue. Recuperación Ambiental.

\section{Introdução}

A reserva Indígena Te'ýikue, no município de Caarapó, Mato Grosso do Sul, está inserida no contexto de oito reservas, no total de 18.297 ha, criadas pelo Serviço de Proteção aos Índios -(SPI) entre os anos de 1915 e 1928. Inicialmente, chamada de Reserva Indígena José Bonifácio, foi criada por Decreto Presidencial em 20/11/1924, com uma área de 3.600 ha, posteriormente, reduzida para 3.594 ha. Juridicamente, a demarcação administrativa se encontra homologada pelo Decreto n. 250 de 29/10/1991 e registrada pela Secretaria do Patrimônio da União -(SPU).

Foi a terceira das oito reservas criadas no sul de Mato Grosso do Sul, cuja finalidade era "aldear os índios que prestavam serviços nos ervais, uma vez que a fazenda campanário, de propriedade da Cia. Matte Larangeira, estava localizada nas proximidades" (MOREIRA DA SILVA, 2002, p. 56). De acordo com habitantes mais antigos, "no começo não tinha mais do que 30 pessoas morando na Aldeia. Tudo era mato fechado, com muita caça e pesca. Dizem eles que usavam o fogo para preparar as roças e que havia muita união e respeito entre as pessoas" (SMANIOTTO; RAMIRES; SKOWROSKI, 2009, p. 12). Com o tempo, a população foi aumentando vertiginosamente, pois, famílias indígenas de outras regiões foram sendo expulsas e levadas para as reservas criadas.

Segundo Eliel Benites (2014, p. 42), “a palavra Te 'ýikue significa te 'ýi (gente, homem) e kue como sufixo da palavra para designar o passado, ou aquilo que já foi; assim, o termo $T e$ ýikue foi sendo traduzido como aldeia antiga". Os nomes das regiões de Te ýikue, segundo os mais velhos, remetem-se a animais, plantas e aspectos geográficos, como: sãka pytã (voçoroca vermelha), mbokaja (coqueiro), jaicha syry (córrego da paca), jakaira (dono do milho), yryvu kua (buraco do urubu), mbopiy (córrego do morcego), ñumbuku (campo extenso), kuchui ygua (bebedouro dos pássaros), kanguery (córrego dos ossos), ju'i rase (choro da rã), mbói passo (passo da cobra), ñandu potrero (potrero de ema), yvu (nascente) e itakuruvi (pedra que amola) (SMANIOTTO; RAMIRES; SKOWROSKI, 2009, p. 19-20).

Este trabalho analisa o papel da educação escolar indígena em Te'ýikue para a construção de projetos de recuperação ambiental da terra. Assim realizou-se um estudo de caso por meio de pesquisa qualitativa com trabalho de campo mediante técnicas de observação direta, conversas, depoimentos gravados e transcritos, diários de campo, caminhadas, registro de fotografia e participação em encontros de professores indígenas. A população de estudo apresenta grupos representativos de idosos, rezadores, professores e lideranças. Como no contexto de Mato Grosso do Sul há terras em litígio e várias demandas pela regularização fundiária, optou-se pela não identificação dos nomes dos interlocutores. Então, suas falas serão marcadas pela categoria principal que representam.

As principais fontes de dados são orais, com base em conversas realizadas em trabalho de campo. Nesse modelo, prevaleceu a conversação livre, mas, com algumas colocações e 
perguntas, foram introduzidos temas na tentativa de chegar às informações recorrentes para cada grupo de pessoas. Além disso, lacunas e os momentos de silêncio foram aproveitados para introduzir alguns dos temas que compuseram o universo da pesquisa.

Foi necessário delimitar a investigação a algumas pessoas centrais que fizeram parte da história da construção do modelo escolar implantado a partir de 1997. Por isso, no que diz respeito ao universo escolar, priorizou-se o contato com as seguintes pessoas: duas professoras da escola de ensino fundamental Ñandejara Pólo (uma indígena e outra não-indígena), o diretor da escola de ensino médio; o professor que coordena o projeto na Unidade Experimental e os servidores do viveiro.

\section{A escola e o tempo}

A educação indígena ${ }^{2}$ está sempre presente na vida das famílias, sendo uma atribuição passada de geração a geração por meio de ensinamentos, de vivências, da oralidade, dentro da cultura, e das interações realizadas interna e externamente. Ela se diferencia da educação escolar indígena, atribuída historicamente a diversas instituições, em que prevaleceu formalmente, até bem pouco tempo, um modelo integracionista.

Inicialmente, as primeiras ordens religiosas católicas que se instalaram no Brasil foram as responsáveis por essa função. Depois, com o SPI, "instalou-se uma rede de escolas para educação de índios com ensino das chamadas 'primeiras letras' e, sobretudo, de ofícios que os situassem como futuros trabalhadores” (LIMA; BARROSO, 2013, p. 49).

Nas décadas de 1980/1990, diversas organizações não-governamentais, a Operação Anchieta (OPAN) e o Conselho Indigenista Missionário - (CIMI) propuseram outros modelos de educação. As conquistas sociais previstas na Constituição de 1988 e as normas regulamentadoras deram suporte normativo para mudanças em curso. O Plano Nacional de Educação, Decreto n. 10.172 de 09/01/2001, principalmente nos artigos 26, 32, 78 e 79, previu a formação superior de professores indígenas, tendo sido o primeiro plano posterior ao art. 214 da Constituição de 1988 e da Lei de Diretrizes e Bases da Educação Nacional (LDB), de 1996.

Em Te’ýikue, "até 1997 a escola da aldeia, em Caarapó, era extensão da escola Tiradentes Pólo, Colônia Saiju, localizada na área rural, e adotava o modelo integracionista e/ou assimilacionista, oferecendo aos índios Kaiowá e Guarani o mesmo currículo das escolas da zona rural” (BATISTA, 2005, p. 14). Era uma educação em português que priorizava os conhecimentos não-indígenas. A evasão escolar e a repetência eram a regra, como demonstram os dados estatísticos levantados no início de 1997. Dados que "comprovaram o descaso das administrações anteriores para com a educação escolar nas escolas da reserva indígena, que tinha, em 1996, 365 alunos, com uma média repetência de $47 \%$ e abandono escolar de $22 \%$ " (BATISTA, 2005, p. 76).

A ideia prevalecente para o professor não-índio era a de que dar aula na aldeia constituía um castigo ou uma perseguição política. Na dissertação de Batista (2005, p.74-75), há um depoimento revelador, de uma professora não-indígena, que trabalhou de 1980 a 1996 na escola

\footnotetext{
${ }^{2}$ É preciosa a lição de Meliá (1979, p.7) sobre o tema: "Educação pode dar-se muito bem sem alfabetização. Alfabetização, no entanto, nem sempre assegura uma boa educação. As sociedades indígenas brasileiras, como aliás, muitas outras sociedades em todo o mundo, se educaram perfeitamente durante séculos sem recorrer à alfabetização, conseguindo, com meios quase que exclusivamente orais, criar e transmitir uma rica herança cultural. A educação baseada na comunicação oral até apresenta não poucas vantagens sobre a baseada na escrita. Nas culturas orais nota-se uma participação mais homogeneizada e plena de todo o saber tradicional, uma grande riqueza de sabedoria proverbial, uma visão mais unitária do mundo, uma forte vivência do presente como tal, uma captação da vida como um todo e não simplesmente acumulação de coisas separadas. A alfabetização, de fato, incentiva a privatização do saber e contribui para um tipo de individualização que logo se manifesta fonte de tensões e conflitos sociais entre dominante e dominado".
} 
de ensino fundamental em Téýikue sobre as dificuldades enfrentadas: falta de transporte, de água, de material escolar e dificuldades de comunicação. De acordo com essa professora, quando ela foi trabalhar na reserva não foi porque queria, era por ser adversária política. Então, foi mandada para lá como castigo para que pedisse demissão. Como ela sabia o guarani por ser descendente de paraguaios, costumava iniciar o processo de alfabetização e depois os alunos seguiam com as demais professoras, já entendendo melhor o português (BATISTA, 2005, p. 74-75).

Diante desse quadro, uma série de esforços começou a germinar no sentido não só de transformação na educação escolar indígena, mas também da melhoria das condições ambientais da terra. Daí, surgiram outras questões como a formação do professor e a melhoria da saúde e do meio ambiente, sendo este um tema transversal da escola.

No início, houve muita resistência de algumas famílias ao ensino na língua materna, pois, entendiam que o guarani já era ensinado em casa e que a escola era o lugar de aprender português e com professores não-indígenas. Então, foi feito um trabalho de reflexão sobre o processo de alfabetização na língua materna, ou seja, como realmente se pensa. A professora não-indígena pontuou que os pais tinham muita resistência com o guarani na escola, pois, pensavam "que se já falavam guarani com nossos filhos, pra quê estudar guarani?"

No princípio, realizaram-se aulas separadas em guarani e em português. Como o resultado dos alunos em guarani foi melhor, os demais migraram. Atualmente, os ensinos de educação infantil e os de $1^{\circ}$ e $2^{\circ}$ ano só ocorrem na língua indígena, do $3^{\circ}$ ano em diante é introduzido o português, e para o $6^{\circ}$ ao $9^{\circ}$ ano há também aulas de inglês, língua ensinada por solicitação dos alunos.

Segundo a professora indígena adotou-se a metodologia dos chamados temas geradores, que conduziram a teoria e a prática escolar a partir das realidades vivenciadas na comunidade: $\mathrm{Na}$ escola, a cada bimestre tem um tema, se trabalham com temas geradores. Por exemplo: meio ambiente, então no primeiro bimestre, a questão da água, do reflorestamento, a queimada. Cada etapa do bimestre, se trabalha determinado assunto. Trabalha na sala e tenta colocar na prática, a importância que traz pra gente. Alguns têm consciência e questionam os adultos, por exemplo quando põe fogo. Antes fazia dos pais ensinar, fica meio ao contrário, dos filhos para os pais, lembrar o que não pode fazer. A maioria dos conteúdos é ligada ao meio ambiente.

A professora não-indígena relembra o início do da transformação do processo educacional:

\begin{abstract}
O material didático era produzido por nós mesmos, aulinha por aulinha,semana por semana. Estudavam e preparavam todo o material pra sala de aula. Um trabalho pioneiro e muito bonito que deu muito resultado. Em 2003, o prefeito ganhou o prêmio Prefeito Criança da Abrinq, em nível nacional. O prefeito pegou uma educação com um resultado péssimo e, em poucos anos, dá uma virada de qualidade e diferenciada pra realidade deles. Nós nos tornamos referência em nível estadual, nacional. Defender um projeto diferenciado que tem que respeitar uma cultura, pensa na dificuldade que é. Porque todo programa que vem, vem engessado, igual pra todo mundo.
\end{abstract}

O ano de 1997 foi o tempo da virada na construção das mudanças operadas em Te'ýikue mediante articulações e muitos diálogos. Várias parcerias entre a comunidade e instituições externas foram realizadas e resultaram em processos de transformação. A parceria entre a Secretaria Municipal de Educação, o CIMI e o Projeto Guarani Kaiowá, da Universidade Católica Dom Bosco (UCDB), foi fundamental para a construção de um novo modelo de educação escolar indígena. Modelo baseado no ensino da língua; numa gestão compartilhada da escola; na valorização do conhecimento da cultura kaiowá-guarani; na construção de metodologias e de recursos didáticos próprios; na formação de professores indígenas para 
atuarem nas escolas das terras indígenas; na criação de cursos específicos, como o de formação de professores para o ensino fundamental, que foi chamado de Ará Verá.

Tal modelo educacional baseou-se, ainda, na construção e realização de projetos ambientais com a participação dos alunos e de suas famílias, da comunidade, de lideranças e de professores. Tais projetos incluíram atividades de extensão e pesquisa, como o viveiro de mudas e a Unidade Experimental; de reflorestamento; de recuperação de nascentes e de microbacias e o desenvolvimento de um fórum de discussões das questões relevantes para Te'ýikue. Segundo Eliel Benites (2014, p. 92), "o espaço escolar foi se caracterizando como uma escola além das paredes. Quando a instituição foi absorvida pela comunidade, desnorteou a rigidez do espaço e do tempo escolar".

O padrão de escola e de recuperação ambiental foi amplamente dialogado com a comunidade, com as pessoas idosas, o que gerou forte envolvimento de todas essas questões. Realizaram-se reuniões, que chegavam a durar um dia inteiro com os mais velhos, professores indígenas e pesquisadores da universidade. A escuta atenta aos problemas foi revelando os porquês, na cosmovisão kaiowá-guarani, do meio ambiente estar na situação em que se encontrava: a vida estava difícil; tinha acabado a mata; o fogo comia tudo. "O fogo entrava num canto da aldeia e saia no outro" como ressaltou a professora não-indígena, "não tinha nada, era só sapé e braquiária. A maioria ficava sem casa porque o incêndio era muito grande".

Essa professora que acompanha desde 1997 o processo de construção da educação escolar em Te'ýikue reconheceu que: "para fazer um trabalho de recuperação ambiental, que é de longo prazo, exige-se mudança de comportamento, de envolvimento". Ela relembrou que, quando Brand (coordenador do projeto à época) conheceu a área anos atrás, ele disse que havia muita erva-mate e mata e que o lugar era lindo. Em dez anos muito foi destruído: "tinha virado sapé e braquiária. Não tinha mais água. Água só nas voçorocas. Os poços sépticos estavam contaminados". Ela ressaltou que dentro de Te'ýikue existem cerca de sete nascentes:

todas as águas da aldeia nascem aqui dentro. É um privilégio. Aqui é um divisor de bacias hidrográficas. As nascentes daqui abastecem a bacia do rio Amambai. As que estão pro lado de lá da MS 280 vão pra bacia do rio Dourados. Alimentam duas bacias. As nascentes saem daqui sem contaminação.

E, seguiu descrevendo com emoção o processo de transformação a partir das intervenções geradas: "a coisa mais bonita da gente ver foi que, na medida em que a gente foi cuidando das matas ciliares, das árvores de proteção das nascentes, a água foi aumentando de novo e onde tinha as voçorocas enormes fizeram as represas". Estas foram feitas com a finalidade de conter a voçoroca, captar água para a comunidade tomar banho, lavar roupa e, ainda, nelas se criavam peixes para ajudar na alimentação, porque havia muita desnutrição.

O modelo da nova proposta de educação foi bastante dialogado, baseando-se no tripé: professores, lideranças e comunidade. Conforme Eliel Benites "com a participação assídua da comunidade nas reuniões houve uma grande mudança na sua dinâmica interna, porque se tornou uma vivência contínua ouvir os 'outros'. A partir desta experiência: "a aldeia começou a se redescobrir, porque muitas demandas saíam destas discussões e redescobertas” (2014, p.81).

As questões ambientais permearam todo o processo, envolvendo a escola com as crianças e a comunidade. A professora não-indígena falou com entusiasmo: "todo mundo era soldado de combate ao fogo pra não destruir as matinhas que a gente tinha plantado. E o que aconteceu de mais bonito? As famílias que entenderam isso começaram a fazer a recuperação em torno da casa deles". Muitas matinhas foram ressurgindo no entorno das casas de muitas famílias. O ciclo desmatamento-braquiária-fogo-desmatamento ampliado foi rompido na medida em que contiveram o fogo e começaram a brotar as arvorezinhas. E, se alguém colocava fogo, havia denuncia e a liderança aplicava castigo. Assim, o meio ambiente foi sendo repovoado. 
Atrás da escola de ensino fundamental Nandejara Pólo foram plantadas as primeiras mudas do viveiro, e cada aluno plantou uma muda com o seu nome e assumiu a responsabilidade de cuidar dela. A professora não-indígena falou sobre o que poderíamos chamar de trabalho de história do ambiente, ou seja, a busca da identificação das espécies que no passado compunham o cenário paisagístico e natural de Te'ýikue:

Como saber o tipo de árvore que tinha aqui? Conversamos com os professores, os pesquisadores. Fizemos um trabalho com os alunos para eles conversarem com os mais velhos da família pra descobrir os tipos de árvores que tinham. Quem sabia escrever, vinha com as listinhas escritas nos caderninhos. Os que não sabiam, falavam os nomes em guarani. Traduzíamos e corríamos atrás da semente ou muda dessas árvores pra trazer pra cá. Porque eram essas árvores que queríamos, que eram nativas.

Depois de identificadas as espécies, o desafio foi encontrá-las para, posteriormente, fazer sua reprodução. Um desses lugares foi a terra indígena de Pirakuá, aonde a equipe de trabalho ia nos meses de agosto e setembro, como destaca a professora não-indígena:

Era a época de semente, íamos com professor, pesquisador, alunos maiores. Acampávamos por duas semanas com duas caminhonetes. Durante o dia a gente ia garimpar as sementes. Voltávamos cheios de carrapato. Voltavam com as duas caminhonetes cheias de semente. Preparávamos, armazenávamos na sementeira. Tinha uma equipe muito atuante no viveiro. Tinha técnico agrícola. Tinha planejamento de coleta de semente, produção de muda, depois escoar essa muda pro meio ambiente.

As transformações do projeto de educação escolar indígena andaram de mãos dadas com o projeto de recuperação ambiental e com a solução de alguns problemas da comunidade. Como ressaltou a professora não-indígena "a escola aqui é uma escola da comunidade". Reconheceu que "a gente errou muito, mas errou junto com eles. E acertou junto também".

Com o plantio das mudas feitas no viveiro, realizaram-se as recuperações da área atrás da escola, da mata ciliar das nascentes da Unidade Experimental e da microbacia. Conforme relembrou a professora não-indígena "foi formando tudo. Pensa nas coisas bonitas que foi virando. Lá pra dentro eles fizeram corredor ecológico, tinha resquício de mata de um lado e do outro, mas os bichinhos não sabiam como passar. Eles plantaram as mudinhas e fizeram a ligação". Os alunos também incorporaram a defesa da mata. Ela relatou:

Se você derrubar alguma árvore aqui no bosque da escola, os alunos pulam na tua cara. Teve que tirar umas árvores nativas pra construir a escola. Houve protesto. Agora fazemos reunião com eles e explicamos tudo. Algumas árvores tiramos com retroescavadeira e plantamos em outro lugar, ou fazemos mudas pra repor. Até com o eucalipto ocorre isso. Já incorporaram. Mas sinto que nos últimos anos tá enfraquecendo isso.

O grande desafio continua sendo manter as matas recuperadas longe do fogo. As árvores dos replantios, mais finas, queimam mais facilmente. Os aceiros constituem uma estratégia importante para prevenir e controlar as queimadas. Mas atualmente devido às dificuldades técnicas e de recursos financeiros, segundo a professora não-indígena, os moradores de Te'ýikue "só ficam correndo atrás quando o fogo já vem. A gente não tem uma equipe que fizesse o planejamento mais amplo e que antecedesse as atividades. Diálogo tem, mas é difícil de fluir as coisas. É a ação".

$\mathrm{O}$ uso do fogo e as queimadas eram e continuam sendo uma das grandes preocupações nas terras indígenas. De elemento tradicional nas práticas de agricultura em um tempo de condições ambientais mais estáveis a ameaça em tempos de braquiária e colonião. A chamada agricultura de coivara foi desestruturada pelo avanço da fronteira agrícola. Com a perda das matas e substituição por essas espécies invasoras, a paisagem nas terras indígenas foi paulatinamente se modificando. A estratégia imediata mais utilizada para limpar a terra para 
fazer as roças é promover a queima, que geralmente não tem controle, e acaba se espalhando por outras áreas, inclusive pelos poucos remanescentes de florestas nativa ou secundária.

\section{Escolas, formação e ecologia de saberes}

Na construção de metodologias destacaram-se as figuras do professor-aluno pesquisador e interventor na comunidade, com o envolvimento das famílias. Optou-se pela utilização de temas geradores (temas de pesquisa e não de disciplinas pré-estabelecidas) a partir das realidades vivenciadas em Téýikue e da realização de planos de aula construídos coletivamente.

Sobre a formação dos professores, a maioria deles passou por processos de educação formal que os distanciou dos saberes da sua cultura. Com a criação de um magistério específico, chamado de Ará Verá, buscou-se fazer a ponte entre as diversas situações interétnicas vivenciadas por eles e o seu saber tradicional. Por isso, a fonte desse conhecimento situou-se na valorização dos idosos e rezadores. Era necessário nutrir-se desse saber, transformar-se como sujeito no papel de professor para trabalhar a educação escolar das novas gerações.

Eliel Benites, que nasceu em Te ýikue, foi aluno das primeiras turmas do Ará Verá e do Teko Arandu e, também professor na sua terra, aborda as dificuldades, mas também o clima de encantamento no processo de construção da escola e do momento que a comunidade passou a viver: "os professores indígenas jovens sentiam muita responsabilidade neste processo, porque assumiam uma postura de líderes antes do tempo. O diálogo com os mestres tradicionais, no primeiro momento, foi doloroso, porque precisávamos nos reconciliar com eles". Mas, "aos poucos foi criado um clima de encantamento no processo de construção da educação escolar indígena, na Reserva Indígena Te'ýikue”(BENITES, 2014, p.88).

A configuração atual das unidades escolares em Téýikue compreende, no ensino fundamental, a Escola Municipal Indígena Ñandejara Pólo e suas extensões em Saverá, no Mbokajá e na região da Missão, chamada de Loide Bonfim Andrade. Devido à demanda pela continuação dos estudos foi inaugurada a Escola Estadual de Ensino Médio Yvy Poty - Flor da Terra.

A Escola de Ensino Médio, que iniciou suas atividades em 2006, é frequentada por aproximadamente 138 (cento e trinta e oito) alunos de ensino médio e 309 (trezentos e nove) de educação de jovens adultos - EJA. A maioria dos professores não é indígena, diferentemente, do que ocorre na escola Ñandejara e nas suas extensões. No ensino médio, as aulas em guarani só são ministradas pelos professores indígenas. Há uma expectativa de ampliação dos professores indígenas devido à formação do Teko Arandu.

Segundo o diretor da escola Yvy Poty: "o intuito era de trabalhar com o jovem a questão ambiental através de aula integral em 2006 em que os alunos estudavam de manhã e a tarde tinham aula prática. Plantavam árvores nas nascentes e trabalhavam na roça coletiva com mandioca e outras plantações". Mas em 2008, a secretaria de educação não permitiu algumas atividades porque não tinha laboratório nem biblioteca.

No ensino médio as disciplinas de geografia e biologia trabalham sobretudo questões ambientais. O diretor da escola Yvy Poty identificou que o maior problema da reserva são as queimadas. Na região do Mbokaja os alunos plantaram cerca de cem mudas, das quais cuidaram, mas ocorreu uma queimada. Ele reconheceu que "mesmo assim, melhorou um pouco com o trabalho da escola. Os alunos levam mudas do viveiro pra casa também. Tem famílias que cuidam bem do seu mato". Sobre a questão do lixo, os professores estão pensando em fazer um ponto de coleta em cada escola para o caminhão da prefeitura, que passa uma vez por semana em cada escola. No âmbito familiar, cada família cuida do seu lixo, mas a maioria o queima. 
O sonho da escola Yvy Poty é oferecer um Curso Técnico em Agroecologia. A estrutura física dos laboratórios já existe, mas faltam equipamentos. Com esse curso, segundo o diretor, a ideia seria "montar pequenos negócios pra os alunos permanecerem aqui. A maioria do pessoal daqui planta mandioca, mas não tem um esquema pra vender pra fora. Os que vem comprar, pagam pouco. Com cooperativa seria uma possibilidade de vender sem atravessador". A criação de pequenos animais, como frangos, seria outra possibilidade, assim como a venda de ovos. Ele disse que assentado e quilombola tem apoio, mas para indígena é mais difícil.

O diretor da escola Yvy Poty pontuou, ainda, que a maioria dos alunos egressos vai trabalhar fora da reserva, principalmente, nas usinas. Uns procuram cursos técnicos, outros a universidade. A minoria segue estudando. Com o curso de Agroecologia, poderiam ser abertas possibilidades de trabalho na reserva. É difícil encontrar trabalho fora de lá. Atualmente, a maioria dos trabalhos internos é ocupada por indígenas, mas não se absorve toda a quantidade de alunos formados.

Os alunos chegam ao ensino médio com experiência de vivências ambientais na Unidade Experimental adquiridas nas atividades do ensino fundamental, mas no ensino médio não existe continuidade de atividades. Há certa ruptura da experiência vivenciada no ensino fundamental. Hoje há uma horta na escola, com recursos do Pronatec. De acordo com o diretor "se a gente tiver o curso de agroecologia vai trabalhar mais a questão ambiental e de sustentabilidade. Esse curso teria a duração de três anos. Nesse espaço, funcionaria a escola de ensino médio e o curso técnico, que pode ser integral, concomitante e subsequente". Segundo ele, a comunidade optou pelo modelo concomitante e subsequente. Ressaltou ainda, que "o conhecimento tradicional tem que vir com o conhecimento técnico. Tem que sempre caminhar junto".

Na visão do diretor, a escola do ensino médio deve dialogar com os mestres tradicionais. E alguns deles cobram, mas ele acha isso certo "porque tem professor de mestrado que cobra pra dar palestra, então eles têm que receber pelo conhecimento deles". Às vezes, ele faz uma cesta e entrega para os rezadores porque no ensino das práticas culturais "o rezador vai passar a prática, o professor, a teoria".

As revelações empíricas desta pesquisa se coadunam com a discussão de ecologia de saberes, de Sousa Santos (2010) e de diálogo de saberes de Leff. O primeiro ao questionar as bases hegemônicas do conhecimento científico, reconhece a diversidade epistemológica do mundo por meio de uma pluralidade ecológica de prática de saberes ${ }^{3}$. Leff (2012), discute o diálogo de saberes ${ }^{4}$ como um híbrido entre ciências, técnicas e saberes, bem como um encontro entre o tradicional e o moderno.

Um espaço importante para a discussão desses saberes ocorreu a partir de 1997 quando foi constituído um Fórum de discussões sobre questões da comunidade, articulado a partir das escolas. Desde então, esse fórum ocorre sistematicamente a cada mês de abril, na semana dos povos indígenas. Segundo, Eliel Benites (2014, p. 95), "este trabalho coletivo dos Fóruns lembra como era nossa vivência tradicional no Tekoha Guasu no passado, quando todos se envolviam para realizar festas e cerimônias religiosas, cada um realizava as ações para um objetivo comum". A professora indígena reconhece:

Todas as conquistas até hoje é devido ao Fórum. Em abril, fazemos reuniões nas escolas para coletar sugestões para o Fórum. Depois, junta tudo e faz um grandão que é na última semana de abril, onde fazemos a Assembleia grande e chamamos as

\footnotetext{
${ }^{3}$ Segundo Sousa Santos (2010, p.157), "trata-se de uma ecologia porque assenta no reconhecimento da pluralidade de saberes heterogénos, da autonomia de cada um deles e da articulação sistêmica, dinâmica e horizontal entre eles. A ecologia de saberes assenta na independência complexa entre os diferentes saberes que constituem o sistema aberto do conhecimento em processo constante da criação e renovação. O conhecimento é interconhecimento, é reconhecimento, é auto-conhecimento".

${ }^{4} \mathrm{O}$ saber ambiental, "forja-se no encontro (enfrentamento, entrecruzamento, hibridação, complementação, antagonismo) de saberes diferenciados por matrizes de racionalidade - identidade - sentido que respondem a estratégias de poder pela apropriação do mundo e da natureza (LEFF, 2012, p.55).
} 
autoridades, aí entregamos os documentos pra eles. Tudo por meio desse Fórum é que temos os avanços daqui. Aqui apesar de ter problema interno na comunidade, mas nós conseguimos trabalhando tudo em parceria. Muitas das outras aldeias que têm esse problema, cada um trabalha no seu cantinho: educação pra lá, saúde pra cá. E aqui não. A gente tenta trabalhar junto.

Em relação às demais terras indígenas com população kaiowá e guarani de Mato Grosso do Sul (MS), Te'ýikue atraiu uma série de projetos e possui um número considerável de professores indígenas que atendem as escolas da sua terra. Sua experiência escolar indígena é paradigmática, assim como o projeto de recuperação ambiental. Conforme atesta Cariaga (2012, p. 106), "desde a década de 1990, Te'ýikue tem sido uma das áreas mais procuradas para realização de muitos projetos de pesquisa, que contam com financiamento". A formação de professores está associada ao cumprimento das normativas pós-Constituição de 1988 por uma educação indígena específica, diferenciada e de qualidade e também aos movimentos políticos da Aty Guasu e do Movimento dos Professores Kaiowá e Guarani.

Em 1999 houve a implantação do curso de formação específica para professores em nível médio Kaiowá e Guarani, chamado Ára Verá (Tempo Iluminado) pela Secretaria de Educação de MS em parceria com as prefeituras dos municípios que tem população kaiowá e guarani. Também foram parceiros desse processo a UCDB, pelo Projeto Kaiowá-Guarani, a UFMS, a Diocese de Dourados e o Movimento dos Professores Kaiowá e Guarani. O Projeto Rede de saberes vem apoiando a permanência de indígenas no ensino superior nas seguintes universidades de MS: UCDB, UEMS, UFGD e UFMS. Além disso, está ligado ao projeto em nível nacional chamado Trilhas do Conhecimento, financiado pela Fundação Ford.

O trabalho de construção de materiais didáticos próprios a partir da realidade vivenciada pelos alunos (futuros professores) de cada terra, também se constituiu como uma ferramenta pedagógica importante para o ensino diferenciado. Quando terminou a primeira turma do Ára Verá foi iniciada a discussão de um curso superior de licenciatura diferenciada. Foram alguns anos de discussão, iniciada no âmbito da UEMS, mas depois assumida pela UFGD onde ocorreu a criação da licenciatura específica chamada de Teko Arandu, atualmente na Faculdade Indígena $^{5}$ (FAIND).

A formação dos professores indígenas por meio de cursos de formação específicos e da ampliação do acesso à universidade no Brasil fez com que houvesse uma ampliação da categoria desses professores e do que se poderia chamar de intelectualidade indígena, tema bastante discutido nacional e internacionalmente. Conforme atesta Lima (2013, p. 24-5):

Essa intelectualidade indígena militante em surgimento e consolidação vem formulando concepções que partem de seu aprendizado - distributivamente variado em suas tradições e do que tais tradições propiciam como chaves de leituras das intervenções de Estado em seus modos de vida, nos contextos locais e regionais específicos de seus povos no presente. Muito dessa reflexão vem sendo cunhada na militância e hoje em espaços acadêmicos de graduação e pós-graduação.

Este processo de formação de professores, de constituição de licenciaturas específicas e da construção da própria escola indígena não é imune a críticas. As principais delas residem nos dilemas entre a educação das famílias e da escola; nas dificuldades de se fazer o diálogo entre saberes indígenas e não-indígenas; na formação do professor; na construção de uma educação que seja realmente específica, diferenciada e de qualidade e na construção da categoria professor indígena.

Mesmo diante destas dificuldades, muito se tem refletido sobre a ruptura de lógicas etnocentristas para se construir uma educação que seja libertadora e apresente caminhos para as novas gerações. Fato é que a escola tem exercido uma centralidade na vida das crianças e

${ }^{5} \mathrm{O}$ Curso oferece Licenciatura plena em Educação Intercultural, com habilitações em quatro áreas de conhecimento: Ciências Humanas, Linguagens, Matemática e Ciências da Natureza. 
das famílias, bem diferente do modo de vida tradicional ideal kaiowá, pois, "a partir da escola desdobram-se muitas ações articuladas a fim de garantirem a ocupação do tempo das crianças, no enfrentamento à violência e como ações que possam 'transmitir valores da cultura' para as novas gerações" (CARIAGA, 2012, p. 160, grifo do autor). Em Te'ýikue, essa centralidade da escola na vida da comunidade "se tornou a estratégia política que busca assegurar a organização interna, diante dos novos problemas, inclusive das questões das quais as famílias dizem que 'a cultura não dá conta' (CARIAGA, 2012, p. 165, grifo do autor).

\section{Renascimento da terra}

Em 1996 começou a ser desenvolvido: "um amplo programa, de caráter interdisciplinar e interinstitucional, de pesquisa e de ações de apoio aos índios Kaiowá e Guarani no Mato Grosso do Sul, denominado Programa Kaiowá/Guarani" (SMANIOTTO; RAMIRES; SKOWRONSKI, 2009, p. 1). Programa que foi coordenado por Antonio Brand da UCDB através do NEPPI e da Diocese de Dourados em parceria com a prefeitura municipal de Caarapó.

A partir desse programa houve um processo de transformações na escola e na comunidade, no sentido de construção de uma educação diferenciada de qualidade e de uma série de ações dirigidas à recuperação ambiental, produção de alimentos, saúde preventiva e história e sociedade Kaiowá e Guarani. O subprograma de Educação Indígena Diferenciada auxiliou na implantação do curso de Magistério Específico, chamado Ára Verá para formação de professores indígenas da educação fundamental.

Já o subprograma de Recuperação Ambiental e Produção de Alimentos baseou-se em várias ações como a recuperação de duas represas e a construção de mais quatro, a criação de um viveiro de mudas, a recuperação da Microbacia de Jakairá, a implantação de Unidades de Pesquisa e Produção de Alimentos e Artesanato (UCDB, 2002, p. 4). E, teve como objetivo:

o estudo do território, recursos naturais e sustentabilidade e processo de comprometimento dos recursos, decorrente do processo de confinamento, incluindo, ainda, o monitoramento da cobertura vegetal, mediante técnicas de sensoriamento remoto e geoprocessamento; recursos e práticas alimentares tradicionais e contemporâneas, plantas medicinais manipuladas pelos Kaiowá e Guarani” (SMANIOTTO; RAMIRES; SKOWRONSKI, 2009, p. 4).

Para tal, foi criado um Plano de Gestão Ambiental na área indígena de Caarapó. O diagnóstico identificou que a mata vinha desaparecendo e a água estava em parte comprometida; a caça, a pesca, a coleta de alimentos e os medicamentos praticamente inexistentes; o solo empobrecido e as queimadas eram constantes devido à presença de colonião ((SMANIOTTO; RAMIRES; SKOWRONSKI, 2009, p. 17).

Foram muitos os desafios identificados para a proposta de gestão. A equipe percebeu que a maior parte deles seria de caráter antropológico e não técnico, como: a aplicação de etnoconhecimentos em práticas de manejo; a participação da comunidade indígena, principalmente, no que toca à prática da agricultura de coivara; o uso do fogo e adoção de novas tecnologias (SMANIOTTO; RAMIRES; SKOWRONSKI, 2009, p. 18).

Um dos objetivos do Plano foi "incentivar o envolvimento da comunidade indígena Kaiowá e Guarani com os ecossistemas locais, fortalecendo e expandindo os seus laços sociais, econômicos, culturais, espirituais e ecológicos, objetivando a busca da sustentabilidade de forma integral, em todas essas dimensões" (SMANIOTTO; RAMIRES; SKOWRONSKI, 2009 , p. 20). Visou também estimular: "a implantação de culturas permanentes consorciadas com as culturas temporárias, viabilizando as chamadas 'capoeiras melhoradas', áreas de roça que poderão se transformar em pomares e bosques, mediante os devidos tratos culturais" (SMANIOTTO; RAMIRES; SKOWRONSKI, 2009, p. 20, grifo dos autores). 
E, na questão de plantios, levou em consideração "a dinâmica da sucessão natural, o tempo e o extrato que as plantas ocupam, o adensamento de plantas, o sombreamento, as podas para 'rejuvenescimento', consórcios adequados, o aumento de massa orgânica, uso de adubação verde e de controles fitossanitários" (SMANIOTTO; RAMIRES; SKOWRONSKI, 2009, p. 20, grifo dos autores).

Serão descritos os projetos relacionados mais diretamente às chamadas questões ambientais $e$ de sustentabilidade, juntamente com as falas de professores e dos atuais cuidadores do viveiro. Eles foram construídos e executados mediante diversos processos a partir de 1996, tendo sido articulados a partir desse Plano de Gestão Ambiental de 2002, com base nos diálogos com a escola, as famílias, a comunidade e o apoio de parceiros externos.

O Viveiro de Mudas está situado ao lado da escola de ensino fundamental Nandejara. Nele, "foi criado um banco de dados fenológico onde se encontram elencadas as espécies que compõem as fitofisionomias ocorrentes na região da Reserva de Caarapó e seu entorno" (SMANIOTTO; RAMIRES; SKOWRONSKI, 2009, p. 27, grifo dos autores). Funciona também como centro de aprendizagem e prática de educação ambiental. Por meio dele foram fornecidas mudas para que as famílias recuperassem o entorno das suas habitações com árvores, principalmente frutíferas, o que foi chamado de Projeto de Fundo de Quintais.

Dentre os quatro servidores indígenas que trabalham no viveiro estabeleceu-se conversas com três. O mais antigo deles, o Servidor 1, dispende mais tempo no local e faz a germinação, o transplante e o plantio. O Servidor 2 trabalha há 11 (onze) anos no viveiro. Ele esclareceu que atualmente há poucas sementes. A procura de sementes ocorre em vários lugares, como nas matas de Te'ýikue, em algumas fazendas, como no Campanário, em que o proprietário permite a entrada e coleta, e na área urbana de Caarapó, onde se encontra jatobá, ingá e cedro. A equipe do viveiro possui um conhecimento sobre como fazer a coleta e as mudas. Como disse o Servidor 2: "a gente já tem a manha, então já coleta. Em agosto e setembro é pra coleta de sementes". E prosseguiu: "dependendo da semente a gente já coloca na estufa ou direto no saquinho. Que nem jatobá vai direto pro saquinho. Tem outra que tem que colocar na estufa e começa a germinar".

Em alguns canteiros, adotou-se a técnica do plantio consorciado, no qual, por exemplo, no segundo canteiro se encontravam pés de angico, jabuticaba, ipê roxo e mamão, todos misturados e, também, fruta do conde, guabiroba, cereja e jequitibá. São quase oito canteiros onde podem ser encontrados ingá, canafístula, poncã, jambo e tubérculos. As hortaliças, como tomate e abóbora, são consumidas pelos servidores do viveiro e suas famílias. As famílias que moram em Te'ýikue podem receber as mudas. Segundo o Servidor 2: "tem família que leva de quinze a vinte mudas. Agora tão incentivando o pessoal aí. Fizemos reunião. Tem família que não tem nenhum pé de sombra na casa". Mas depois que as famílias levam as mudas, a responsabilidade de cuidar pertence a elas.

O Servidor 3 trabalha no viveiro há cerca de onze anos. Ele se referiu à época em que o pessoal da UCDB estava com eles e da existência de recurso. Por isso, conseguiram fazer o viveiro e um trabalho preventivo das queimadas, pois se fazia aceiro com o uso de trator e tinha combustível. Agora ele reclama que "acabou. Não tem mais estrutura adequada pra trabalhar. Semente tá meio parado. Nós sempre planta na beira dos açudes, na represa. Por três vezes, nós plantemos na nascente ali em baixo, mas o fogo vai lá".

O Servidor 1, um dos pioneiros do trabalho no viveiro, conhecia muitas árvores nativas do local. Afirmou que existem "quarenta e oito variedades de árvores. Tem aroeira, peroba rosa, jequitibá, canafístula, cedro". Pelo projeto de recuperação, ele descreveu que depois que as mudas se formaram, eles começaram a plantar na escola e na microbacia, onde existia muita braquiária. Ele mostrou algumas árvores por trás da escola que já estão grandes, mas que levaram quinze anos para atingir aquela altura. O Servidor 3 disse que atualmente a escola está sem projeto de replantio, mas às vezes o pessoal do viveiro faz algumas ações pontuais. 
Sobre as projeções do A aldeia que queremos o Servidor 3 disse que "o projeto do corredor ecológico não avançou muito". O local com mais vegetação está situado nas regiões de Mbopiy e Yvu. Ele disse que o controle das queimadas está difícil atualmente. Em sua fala: "nós tinha falado com a prefeitura pra arranjar 200 litros de óleo por mês pra fazer aceiro. Mas o nosso trator tá quebrado. Tá parado. Foi trator do projeto da UCDB. Mas tem problema pra conseguir combustível, manutenção". A comunidade também não está colaborando, segundo ele: "tem que fazer palestra. A gente começou a fazer no Mbopiy e na Missão e deu certo. Aí depois pararam". Perguntado sobre como eram essas palestras, ele pontuou que "chegava, conversava com a comunidade, falava a importância do matinho, de não queimar, o que a matinha faz". Isso acompanhado de alguns professores e da liderança. Mas "hoje a liderança tá parado, não se envolve muito nessas questões. O certo era fazer uma palestra bem feito com eles. A importância das matinhas".

Segundo o Servidor 1, a própria mata, através do plantio de árvores, acabou com a braquiária: "a sombra mata". Então, alguns animais voltaram pra lá, como jacu e tatu. Mas ele observou diferenças entre a mata nativa e a que foi replantada, porque "a árvore plantada tá em fileirinha. E a nativa já não, parece que tem mais hábito, se habitua mais”. Eles procuraram diversificar o plantio das espécies em uma mesma área. E o viveiro fornecia as sementes. As árvores nativas têm uma casca mais grossa. Onde ficava a mata nativa há outras árvores próximas, o mato é fechado e na mata plantada é mais aberto. O Servidor 3 falou do projeto sobre quintais para plantas frutíferas, nos anos de 2003 e 2004, quando foram plantadas árvores em várias casas. Principalmente poncã, tangerina, manga, banana e acerola. Muitas famílias participaram do projeto e têm nos seus quintais as frutíferas.

Quanto aos corredores ecológicos previstos no plano de gestão, alguns conseguiram se formar, como o que está na Unidade Experimental, em Mboipaso, conforme atestou o professor da unidade. Foi prevista a recuperação da vegetação ciliar, "com base na sucessão ecológica e utilização de mudas produzidas no próprio viveiro da Reserva". Sendo "priorizados os locais com maior nível de degradação e aqueles que foram indicados como prioritários pela comunidade na elaboração do plano" (SMANIOTTO; RAMIRES; SKOWRONSKI, 2009, p. 24). E, também, o reflorestamento para uso coletivo com espécies de rápido crescimento, aproveitando vazios ou áreas degradadas para madeira e lenha com fins diversos, inclusive para construção e reparação de casas. É o caso da área central onde houve o plantio de eucalipto.

Houve a construção de uma represa junto ao córrego Mbopey que visou à contenção de erosão ao longo desse córrego com diminuição de assoreamento e aproveitamento de energia hidráulica por meio de bombeamento de rodas d’água, piscicultura e lazer (SMANIOTTO; RAMIRES; SKOWRONSKI, 2009, p. 26).

Foram feitos plantios de enriquecimento junto a fragmentos florestais visando a favorecer a diversidade biológica e a ampliação da base genética de espécies (SMANIOTTO; RAMIRES; SKOWRONSKI, 2009, p. 26). Segundo Eliel Benites (2014, p. 120), “o plantio das árvores nativas tem por objetivo recuperar as nascentes, as microbacias, os corredores ecológicos, trazendo de volta os donos das matas (ka'aguy jára), dos animais, das plantas”.

Quanto à educação, "os alunos começam a compreender que as árvores são como pessoas que estão morando na aldeia e que precisam ser respeitadas e valorizadas, num outro tipo de relação com o meio ambiente, constituindo um novo modo de ser kaiowá e guarani no processo de recuperação ambiental" (BENITES, 2014, p. 121). A educação ambiental foi considerada como algo central para a execução do Plano, entendida no seu: "caráter interdisciplinar, integrando a comunidade indígena, escolar, instituições e parceiros envolvidos, adequando conteúdo programático básico com atividades específicas quanto ao conhecimento cultural e tradicional sobre manejo e utilização dos recursos naturais". (SMANIOTTO; RAMIRES; SKOWRONSKI, 2009, p. 28-29). 
Ao mesmo tempo em que se deu um apoio ao desenvolvimento da agroecologia tendo como atividades: formar agentes agroecológicos; motivar os agricultores indígenas para a produção agroecológica; promover capacitação em agroecologia para os agricultores indígenas; ampliar as Unidades de pesquisa, produção de alimentos e artesanato; apoiar a produção de insumos alternativos (composto orgânico, biofertilizantes e defensivos alternativos); formar um banco de sementes de variedades agrícolas tradicionais, espécies nativas e adubos verdes; apoiar a implantação de sistemas agroflorestais (SAFs). (SMANIOTTO; RAMIRES; SKOWRONSKI, 2009, p. 30-36).

\section{A unidade dos experimentos dialogados}

O Projeto das unidades de pesquisa, produção de alimentos e artesanato ou simplesmente Unidades Experimentais ou Projeto Poty Reñoi (o nascimento da flor) pretendeu, inicialmente, apoiar a permanência dos alunos na escola visando a minorar a evasão e a repetência. Iniciou-se em agosto de 2001 com as parcerias do Programa Kaiowá-Guarani da UCDB, da Prefeitura de Caarapó e de um órgão do Estado de MS, chamado IDATERRA (SMANIOTTO; RAMIRES; SKOWRONSKI, 2009, p. 33-34). A professora não-indígena descreveu o que motivou a criação da Unidade Experimental:

A juventude indígena, essas novas gerações se distanciou muito da cultura indígena. Historicamente, os Guarani-Kaiowá são pequenos agricultores. São coletores também. Mas sempre produziram as rocinhas deles de coivara pra se alimentar. E essa coisa foi acabando. O que acontece? Os homens vão pra usina, um trabalho doido, se matam lá, vêm com dinheiro, vai pro mercado e compra até a mandioca já empacotadinha limpa. E aí essa meninada vai com quem pra roça? Vai aprender com quem? Tem que ter alguma coisa disso junto com a escola, né. Aqui quando os meninos tinham 12 anos pegavam registro de adulto e iam pra usina ganhar dinheiro e abandonavam a escola. Casava cedo. Era um desastre. Dificilmente um aluno de 14, 15 anos ficava na escola. Era o único jeito que eles enxergavam a vida aqui dentro. Como é que a gente faz pra reverter isso? Aí começamos. No governo do Estado foi estabelecida uma bolsa pra manter o aluno na escola. Eles ganhavam a bolsa com as atividades complementares da Unidade Experimental e atividades de artesanato, de esporte, informática e pesquisa bibliográfica e de campo, sobre cultura, natureza, plantas medicinais.

No início do projeto, eram setenta alunos e para mantê-los na escola havia uma bolsa de R\$ 70,00 de um Programa do Governo do Estado que começou com atividades de produção de alimentos. Após alguns anos, as bolsas não foram mais disponibilizadas e a identidade do projeto foi se transformando. Então, ele passou a ser visto como um espaço de vivência e adotou práticas de sistemas agroecológicos. Atualmente, atende alunos do ensino fundamental do $4^{\circ}$ ao $9^{\circ}$ ano e algumas famílias da comunidade. (BENITES, 2014, p. 104-117). A partir do $4^{\circ}$ ano, o aluno vai para lá uma vez por semana para fazer atividades. O Projeto é ligado a todas as extensões da escola de ensino fundamental Ñandejara. O objetivo específico definido no Projeto Político-Pedagógico é:

Fazer com que os alunos percebam a importância da terra dentro da cosmologia tradicional, através do cultivo, do manejo, do reflorestamento das plantas que oferecem alimentos e bem-estar a sua família, realizar plantio de sementes tradicionais como forma de fortalecimento e manutenção das espécies nativas Guarani Kaiowá. (BENITES, 2014, p. 116).

A Unidade Experimental é semelhante a um laboratório da comunidade. Desde o início desempenha uma função pedagógica-escolar, visando à manutenção do aluno na escola e à aproximação deste com práticas e vivências culturais e de agricultura. A unidade utiliza técnicas de adubação orgânica, plantio consorciado, inseticida natural e manejo de ervas daninhas. 
O apoio à agricultura das famílias também é uma atividade que faz parte das suas funções, variando no tempo o número de unidades familiares atendidas a depender da estrutura de apoio existente. Muitos parceiros não-indígenas contribuíram de diversas maneiras para sua concepção e desenvolvimento. Participações que foram desde o apoio para estrutura física à filosofia das técnicas a serem adotadas. A recuperação das nascentes, o renascimento da mata, a construção da represa, frutos do Projeto Kaiowá-Guarani foram importantíssimos para a criação de um ambiente adequado ao desenvolvimento das atividades e ao envolvimento dos alunos e das famílias.

A atitude reflexiva sobre as técnicas e alternativas de recuperação da natureza e da produção de alimentos guiou vários experimentos. A adoção da agricultura orgânica com aplicação de adubos verdes e inseticidas naturais reflete essa postura. Nesse sentido, o uso de sementes nativas e de sistemas consorciados e agroflorestais parecem se harmonizar com a cultura kaiowá-guarani aliando conhecimento tradicional e técnicas modernas de manejo.

A experiência da Unidade mostra as inúmeras possibilidades de criação e de desenvolvimentos das diversidades biológica e cultural. Ela revela como é rico, belo e possível conviver na e pela diversidade, que se pode unir diversas gerações com um mesmo propósito, que a cultura se transforma por meio de conhecimentos que se harmonizam, e que os encontros e diálogos são estimulantes e inspiradores. A Unidade é um oásis de vida e de esperança para índios e não-índios.

O professor atual da unidade começou em 2011 a trabalhar no espaço onde muitos professores trabalharam. Sobre as atividades com os alunos do $4^{\circ}$ ao $9^{\circ}$ ano, ele disse que o planejamento se dá de acordo com o nível da turma, em uma hora e meia de atividades. O tempo é utilizado para conversar e praticar.

Já com as famílias o trabalho é de orientação. Elas têm compromisso com o banco de sementes, ou seja, pegam, plantam e quando colhem, devolvem a mesma quantidade para alimentar o repositório de sementes e também repassam para outras famílias com a finalidade de multiplicar o conhecimento.

A produção agroecológica também é estimulada. A Unidade chegou a atender oitenta famílias, mas os professores viram que a dificuldade cresceu, então foi necessário diminuir para quarenta. Atualmente, são dez famílias nesse projeto e os professores atuam bem próximos a elas, que também se comprometeram a recuperar a área no entorno de suas casas.

O professor narrou que antes do reflorestamento da área da Unidade havia muita braquiária e o solo era muito pobre. Mas, como há nascentes dos dois lados da área, começou a ocorrer o processo de transformação. Foram usadas técnicas de agroecologia, de adubação verde e de compostagem. Foi feito o minhocário, com minhoca californiana (trazidas por dois pesquisadores da Embrapa) que produz o húmus. O professor refletiu sobre as condições ambientais do passado e as existentes atualmente quanto ao uso do fogo:

Naquela época era árvore, mata. Aí plantava. Só que hoje isso não funciona mais. Hoje é capim, braquiária, colonião, sapé. E se você limpar com fogo, no dia seguinte já tá tudo brotando. Essa técnica que a gente tenta tirar. E colocar um novo. A realidade que a gente vive hoje mudou muito. O espaço tá pequeno e muita gente. A gente tem que saber produzir no mesmo espaço sem prejudicar o meio ambiente e sem prejudicar a produção também. O uso do veneno, que isso seja evitado.

A principal ameaça ambiental da reserva, segundo a visão do professor, é o fogo:

Por que ele vai desmatando, destruindo, vai acabando com a variedade de espécie. Aí só nasce braquiária, colonião, sapé. O pessoal coloca mais fogo na braquiária. A mata chegava no terreiro. Mas como foram destruindo, aí ela não consegue se recuperar, aí a braquiária vai tomando conta. Aí fica mais fácil de queimar. Não tem o controle, eles não fazem o aceiro. Tem pessoas que botam fogo pra limpar o terreno, e outras pessoas veem uma cobra e já quer se livrar do mato. 
Sobre as formas de combater a braquiária e o colonião, a orientação da Unidade é utilizar o adubo verde. Essas espécies não convivem bem com a braquiária, conduzindo-a a um sufocamento. A Unidade orienta as famílias para usarem feijões, como mucuna e guandu, para combater a braquiária:

a mucuna sobe nas árvores, é trepadeira e sufoca mesmo. E o guandu é porque é uma árvore, arbusto e faz aquela sombra. Elas vão arando, arejando o solo e aí produz matéria orgânica. E pro colonião é a mesma técnica. A gente pede pras famílias não botarem, fogo. Cortar o colonião, que a própria palha vai abafando a raiz. A gente fala do solo que a gente tem que deixar coberto.

O professor da unidade, nascido e criado na reserva, concluiu o Teko Arandu e faz pósgraduação em educação na UFGD, revela um forte sentimento de pertença ao lugar. Sobre o seu papel na Unidade, revelou:

a gente vai lutando pra mudar pelo menos um pouquinho. A gente quer se tornar
independente. Porque viver na dependência é muito difícil. A maioria das famílias
fica dependendo muito do governo. Espera semente, trator, combustível da Funai. A
época não espera, vai passando. E as sementes que vêm da Funai são de péssima
qualidade. Aí a pessoa planta e acaba se decepcionando com o resultado.

$\mathrm{Na}$ casinha onde fica o depósito das sementes, o professor mostrou com entusiasmo, várias delas, como milho (de várias cores: branco, vermelho e mesclado, com seis espécies), feijão (com vinte e três espécies), amendoim, gergelim preto, arroz (de três espécies: bico preto, amarelão e agulhinha), dentre outras. A casca de arroz é utilizada para adubar o solo. Sobre a conservação das sementes, o professor disse: "antigamente, conservava em cima da fogueira, aí a fumaça não deixava o caruncho estragar a semente. Hoje a gente tá tentando guardar nas garrafas. Aqui você só pode abrir e plantar. Senão, entra e estraga”. As famílias pegam para plantar, levando um saquinho ou uma garrafinha. Hoje em dia, o professor exerce, dentre muitas atribuições, o papel de guardião das sementes. Perguntado se as atividades que são realizadas na Unidade são chamadas de Educação Ambiental o professor respondeu que sim, mas "na verdade, o índio não tem o hábito de classificar as coisas, de dividir. Ele vê o todo”.

Embora as definições e as classificações científicas não sirvam apropriadamente para enquadrar as experiências indígenas, a noção de educação ambiental crítica, trazida por Vasconcelos e Tozoni-Reis (2014, p.113), como uma "dimensão transformadora e emancipatória, cujo principal objetivo é construir, de forma radicalmente coletiva e participativa, novas relações com o ambiente que sejam ecologicamente equilibradas e socialmente justas", se aproxima das práticas verificadas na terra indígena em estudo. Verificaram-se experiências na educação escolar indígena formal e não-formal com diálogos entre saberes científicos e conhecimento tradicional, rompimentos de disciplinariedade, ações intra e extraescolar. As articulações ocorrem num nível de ação educativa, de investigação científica e de participação social.

Neste sentido, compartilha-se da visão de Carvalho (2004, p. 154) que entende a educação ambiental como "uma proposta educativa que nasce em um momento histórico de alta complexidade. Faz parte de uma tentativa de responder aos sinais de falência de todo um modo de vida, o qual já não sustenta as promessas de felicidade, afluência, progresso e desenvolvimento".

A proposta integradora, interdisciplinar, transformadora de realidades e emancipadora da Unidade experimental enfrenta dificuldades. Atualmente, poucos trabalham no projeto da unidade e está difícil levar algumas tarefas adiante. Há apenas mais um professor na Unidade e eles contam com o apoio da Associação dos Produtores Orgânicos do MS - (APOEMS), que é a instituição mais presente atualmente. Há dois técnicos que prestam assessoria na última semana de cada mês. 
Lá são produzidos inseticidas orgânicos com diversas espécies e com várias técnicas. Um deles é feito com cebolinha e, atualmente, a maior ameaça é a lagarta. Outros inseticidas naturais são o fumo, a pimenta e o nim (plantinha que segundo o professor é a melhor de todas). As famílias apoiadas pela Unidade produzem mais - são produtos sem agrotóxicos - para uso interno. Segundo o professor, quem vem de fora, frequentemente do município de Caarapó, para comprar quer pagar pouco. Em geral, são alimentos como mandioca, abóbora e batata. A unidade tenta orientar para evitar exploração. Em Te'ýikue não há feira para trocar produtos. Conforme o professor, eles pensaram em fazer uma feira, mas o projeto não deu certo.

$\mathrm{Na}$ época do plantio há reunião, depois eles trocam sementes, pois confiam no trabalho da Unidade. As famílias retiram as sementes, então as devolvem. A troca de excedentes ocorre, principalmente, entre os parentes. A horta também complementa a merenda da escola, mas a escola, apesar de consumir parte dos alimentos produzidos, precisa complementar com os enviados pelo município.

Segundo o professor, a horta possui várias espécies, dentre elas: as alfaces americana, roxa e crespa. O coentro é novidade, ninguém cultivava. Comer hortaliças não é da ancestralidade, mas eles estão tentando introduzir: "o alface é bem aceito. A cebolinha e salsa já não vai. Eles não gostam de coentro, beterraba, almeirão, jiló". Na verdade, ele considera que as verduras não aceitas devem-se ao fato de "não saberem prepara-las ainda. Porque na escola, as cozinheiras colocam até a folha da beterraba no feijão e as crianças comem, sem saber". E, complementa: "o brócolis também, esse também tá sendo bem aceito na escola".

O professor mostrou várias plantações bem sucedidas em SAFE. Uma delas é com banana, laranja, cará, milho e açafrão: "em volta das frutas, a gente planta o feijão de porco. As formigas não chegam nele e evita fungo. Faz um círculo". A Unidade tenta plantar no sistema consorciado, no qual trabalham com duas ou três espécies, dependendo do que se vai plantar, "aí faz essa mistura, essa bagunça, como abacaxi com cana". Ele foi revelando que na natureza não existe uniformidade e, sim, diversidade ${ }^{6}$. A Unidade produz, ainda, mudas, como as de pimenta amarelinha ardida, pimentão e berinjela. Lá existe uma estufa pequena, então, quando é necessário expandir, utilizam a estufa do viveiro que tem mais estrutura.

Existe dificuldade de conscientizar as pessoas para não cortarem a mata, pois, muitos precisam de madeira para fazer casa e/ou chiqueiro. Essa percepção também é compartilhada pela professora não-indígena que relembrou: "a Unidade é a microbacia recuperada. Ali não tinha nada. Há uns moradores novos que tão indo pra lá com foice e cortam onde reflorestamos com o apoio dos alunos e moradores antigos da área. Eles não sabem da história. Eu não vejo mais reunião da comunidade".

No projeto de recuperação ambiental, a maior parte da comunidade de Te'ýikue se envolveu. A visão de mundo tradicional das espécies sagradas, da utilização das espécies, das rezas foi cultivada. Para o professor, "essa ligação com a natureza é muito forte ainda. Eu tava conversando com um colega que dizia: parece que a cultura tá num leito de hospital. O modelo de vida do não-índio tá vindo com muita força e a gente não consegue segurar isso. E a gente precisa selecionar o conhecimento ocidental".

Eles receberam a herança de muitos processos de destruição e de modelos de utilização dos recursos naturais muito diferentes dos que viviam. Era um mundo com melhores condições ambientais. Muitas questões tradicionais têm dificuldade de lidar com as condições que são colocadas hoje. Por isso, é necessário visualizar os caminhos para lidar com a situação atual,

\footnotetext{
${ }^{6}$ Existem diferenças significativas entre as formas de cultivo e o grau de utilização dos recursos naturais entre sistemas monoculturais e a agricultura nativa. Segundo Shiva (2003, p. 56-58), nas monoculturas há o predomínio da "integração de sementes e os produtos químicos", visando tornar uma cultura "extremamente produtiva" o que gera uma série de impactos ecológicos negativos. Na agricultura nativa prevalece uma "relação simbiótica entre solo, água, plantas e animais domésticos", em sistemas de "rotação de culturas" complexos e diversificados com insumos orgânicos.
} 
porque, por exemplo, no passado mais remoto não existia a braquiária. É necessário construir um conhecimento para lidar com ela. A Unidade já tem uma teoria e uma prática.

Para o professor, a sobrevivência do indígena não deve estar no trabalho assalariado, nas usinas e nas fazendas. Mas sim no cultivo da terra, com a melhoria da produção alimentar. Muitos não conseguem "enxergar que ele pode produzir aqui, na própria terra. Outra coisa, é o mau planejamento dos governos. Eles acham que o que vai funcionar no assentamento, vai funcionar na aldeia". Segundo ele, o que atrapalha muito são as políticas públicas, pois:

A pessoa aposentada fica dependente daquilo. Aí deixa de cultivar, abandona muito coisa da cultura. São muitas coisas que a gente sente que atrapalha mesmo. O mais velho enxerga a simplicidade de viver. Já os mais novos não quer saber. A resistência tá com a geração mais nova de não querer aceitar. Querer viver o modelo de vida nãoindígena. Acha que é melhor. Avaliando bem, muita coisa não é boa, como a alimentação mesmo.

Ele vê gente com trinta, quarenta anos sofrendo de pressão alta, de diabetes e de muitas doenças:

A gente tenta refletir isso com as crianças, quando eles vêm. Eles têm que saber selecionar. Viver bem assim na comunidade. Que a gente acredita que a melhoria tá na produção alimentar. Que tem que partir daí. Não é pela cesta básica. Aqui tem família que depende totalmente da cesta básica

E por outro lado, há muitos casos de obesidade na reserva, pois, "a alimentação é totalmente contrária. Tem poucas famílias que produzem pra consumo. A maioria trabalha na usina, quase mil homens e, o pessoal que trabalha nas obras da rodovia". Segundo o professor, eles discutem: "sobre o modelo de vida caro, que muitos querem adotar. O não-índio paga pra emagrecer, vai na academia, tudo caro. E o índio não, tem a represa faz a natação; tem a mata, faz uma caminhada".

O professor da Unidade acha que o projeto de recuperação ambiental avançou mais na região central e no Mbopiy, onde mora um dos rezadores, pois esse rezador: "tem um contato muito forte com a escola em relação à preservação ambiental. Ele vem, aprende com nós, a gente aprende com ele também. E ele leva isso pra família dele também. Então, fica bem mais fácil de trabalhar alî". O rezador de Mbopiy é um líder espiritual para Te'ýkue. Segundo o professor: "o pessoal procura muito ele para benzer, fazer remédio caseiro. Ele é uma pessoa super aberta pra dialogar".

Em Te’ýkue há o predomínio de uma família ou parentela em cada região. O professor revelou que: "descendo o Mboipaso são famílias de diferente parentela e acabam não se entendendo. E não tem o líder, cada uma é separada". Há uma dificuldade em lidar com moradores novos que não acompanharam o processo de construção da escola e da gestão ambiental após 1997. Na região de Saverá, onde existem remanescentes de mata atlântica há uma maior pressão ambiental para utilizar a madeira das árvores na construção de casa, cerca, chiqueiro e para lenha.

O projeto do Plano de Gestão Ambiental em Te'ýkue foi encerrado em 2010, teve resultados positivos perante à comunidade, como a construção de uma represa, com aproximadamente 12 hectares de lâmina d'água, sendo utilizadas para pesca e recreação; a produção e o plantio de mudas nativas; recuperação de nascentes e áreas degradadas e consolidação da temática ambiental" (SMANIOTTO; RAMIRES; SKOWRONSKI, 2009, p. $1)$.

\section{Considerações Finais}

O legado do envolvimento da escola, da comunidade e dos parceiros é algo bastante significativo e sentido positivamente por todos os interlocutores da pesquisa. Porém os desafios 
também são expressivos. Preservar o legado dos projetos construídos em nível comunitário e levados adiante pelas famílias e a ampliação dos projetos escolares e de conservação ambiental são questões relevantes nesta conjuntura.

Do ponto de vista ambiental, o adensamento demográfico em franco crescimento com mais pressão sobre os fragmentos de mata; as constantes queimadas, em que pesem os esforços para combatê-las; o não envolvimento dos novos moradores, por vários fatores, nas medidas de conservação; os riscos do distanciamento das novas gerações da cultura e das coisas da terra, dentre outros, desafiam professores, famílias e comunidade.

Há um saudosismo da época em que a equipe interdisciplinar do Projeto Kaiowá Guarani estava presente na vida da reserva. É visível o legado do projeto e como várias parcelas da comunidade incorporaram os seus benefícios, que vão da educação à transformação dos seus quintais. Mas percebe-se um vácuo entre a época das atividades mais intensas do projeto e o presente, no sentido de levar adiante as conquistas. Pairam dúvidas. Preocupações para não perder o encantamento do passado recente. Várias falas se manifestaram no sentido de "agora tá parado porque não tem mais assistência”.

O diálogo de saberes na diversidade da vida revela a importância da interculturalidade para a construção de uma sustentabilidade voltada à recomposição da vida e à minoração de processos de colonização que resultaram em profundas transformações culturais e ambientais. Um dos inúmeros desafios para se alcançar a sustentabilidade em bases interculturais seria harmonizar os conhecimentos étnicos com conhecimentos não indígenas paras as práticas de recuperação da terra e de manejo ambiental.

Os kaiowá-guarani têm muito a ensinar para a construção de uma sustentabilidade da e pela vida que incorpora uma dimensão espiritual que passa pelo pertencimento da sociedade a um dado território, para estimular e promover mudanças. O que implica viver a sustentabilidade na diversidade de saberes, dialogando sobre a construção de consensos para intervenções práticas que digam respeito aos usos naturais e culturais de uma determinada terra e gente.

É necessário pensar em transformar paisagens monoculturais em paisagens com diversidade de mato, como foram assim um dia. O modelo de educação escolar indígena de Te'ýikue, baseado em diálogo de saberes entre rezadores, idosos, professores, alunos e suas famílias aproximando gerações; o Projeto Kaiowá-Guarani de recuperação ambiental; a adoção de sistemas agroecológicos na unidade experimental de Te’ýikue; a demanda por casas de rezas e por uma educação diferenciada e de qualidade parecem oferecer pistas para o futuro e apontar caminhos.

É importante pensar modelos de recuperação ambiental para as terras indígenas com projetos a partir da comunidade, com formas mais inovadoras de condução e de financiamento para os projetos ou por serviços e produtos gerados internamente como alimentos orgânicos, sementes crioulas e mudas nativas. Isto a partir de contextos de sistemas agroflorestais para se pensar em novas economias alternativas voltadas para o reflorestamento e a recuperação ambiental.

A educação escolar indígena também pode contribuir para a educação não-indígena. Aspectos importantes como o envolvimento das famílias e da comunidade em projetos educacionais, a figura do professor-pesquisador com práticas docentes pautadas na pesquisa da cultura étnica e local, a elaboração de materiais didáticos com base na realidade vivida e não a simples adoção de materiais homogeneizadores indicam o quanto temos que aprender com eles.

$\mathrm{O}$ modelo de alfabetização ecológica ou educação ambiental de Téýikue sinaliza caminhos para repensar modelos vivenciados nas famílias e nas escolas de não-índios. O que revela como esta temática pouco avançou em termos de práticas e hábitos cotidianos na sociedade não-indígena, visto que os processos de degradação ambiental e as pressões por recursos naturais e de consumo só ampliaram as contradições do modelo de desenvolvimento que vivemos. 


\section{Referências}

BATISTA, Teresinha Aparecida da Silva. A luta por uma escola indígena em Téýkue, Caarapó/MS. 2005. Dissertação (Mestrado em Educação) - Universidade Católica Dom Bosco, Campo Grande, 2005.

BENITES, Eliel. Oguata Pyahu (uma nova caminhada) no processo de desconstrução e construção da educação escolar indígena na reserva indígena Téýikue, 2014. Dissertação (Mestrado em Educação) - Universidade Católica Dom Bosco, Campo Grande, 2014.

CARIAGA. Diógenes Egídio. As transformações no modo de ser criança ente os kaiowá em Te 'ýkue (1950 - 2010). 2012. Dissertação (Mestrado em História) - Faculdade de Ciências Humanas, Universidade Federal da Grande Dourados, Dourados, 2012.

CARVALHO, Isabel Cristina de Moura. Educação ambiental: a formação do sujeito ecológico. São Paulo: Cortez, 2004.

LEFF, Enrique. Aventuras da epistemologia ambiental: da articulação das ciências ao diálogo de saberes. São Paulo: Cortez, 2012.

LIMA, Antonio Carlos de Souza. Cenários da educação superior de indígenas no Brasil, 20042008: as bases e diálogos do Projeto Trilhas de conhecimento. In: LIMA, Antonio Carlos de Souza, BARROSO, Maria Macedo (Orgs.). Povos indígenas e universidade no Brasil: contextos e perspectivas, 2004-2008. Rio de Janeiro: E-papers, 2013.

LIMA, Antonio Carlos de Souza, BARROSO, Maria Macedo. A presença indígena na construção de uma educação superior universal, diferenciada e de qualidade. In: LIMA, Antonio Carlos de Souza, BARROSO, Maria Macedo (Orgs.). Povos indígenas e universidade no Brasil: contextos e perspectivas, 2004-2008. Rio de Janeiro: E-papers, 2013.

MELIÁ, Bartolomeu. Educação indígena e alfabetização. São Paulo: Loyola, 1979.

MOREIRA DA SILVA, Lásaro. A legitimidade do processo de retomada das terras tradicionais pelos índios Kaiowá e Ñandéva em Mato Grosso do Sul. 2002. Dissertação (Mestrado Interinstitucional em Direito Constitucional) - Centro Universitário da Grande Dourados/Universidade de Brasília, Brasília, 2002.

SANTOS, Boaventura de Sousa. A gramática do tempo: para uma nova cultura política. 3. ed. São Paulo: Cortez, 2010.

SHIVA, Vandana. Monoculturas da mente: perspectivas da biodiversidade e da biotecnologia. São Paulo: Gaia, 2003.

TOZONI-REIS, Marília Freitas de Campos, RAMOS DE VASCONCELOS, Hedy Silva. A metodologia de pesquisa-ação em Educação Ambiental: reflexões teóricas e relatos de experiências. In: PEDRINI, Alexandre de Gusmão, SAITO, Carlos Hiroo (Orgs). Paradigmas metodológicos em Educação Ambiental. Petrópolis: Vozes, 2014.

SMANIOTTO, Celso Rubens, RAMIRES, Lídio Cavanha, SKOWRONSKI, Leandro (Orgs.). Atlas socioambiental terra indígena Te ýkue. Campo Grande: UCDB, 2009. 